\title{
Luxor, Endlessness and the Continuous Key: Architecture and the Esoteric in Breton, Kiesler, and Schwaller de Lubicz
}

Dennis Maher

\begin{abstract}
"Now, function is action... The cause is metaphysical cause first, and as soon as it enters into the way of realization of the effect that it generates it becomes active cause. Whatever the form of action may be, there is an activity which is cause."
\end{abstract}

-R.A. Schwaller de Lubicz (Nature 55)

\begin{abstract}
"Form does not follow function-function follows visionvision follows reality."
\end{abstract}

-Frederick Kiesler (Manifesto 94)

\footnotetext{
"Pure psychic automatism, by which one proposes to express, either verbally, in writing, or by any other manner, the real functioning of thought."
}

-André Breton (Manifestoes 26)

In André Breton's Arcanum 17, the myth of Osiris echoes as a dark and persistent whisper. At various points within this extended meditation, the veteran surrealist, writing amid the isolation of a coastal Canadian landscape, conjures the Egyptian god, whose story of destruction and resurrection mirrors the events - mental and material - of his own life in 1944. In so doing, Breton unlocks the door to a newly emergent surrealist myth at a time of intense upheaval and casts fresh light upon a shifting cultural and political context. Arcanum 17 has been read by many, including Anna Balakian, as an attempt "to find light and hope in the bleakest year of World War II by 
seeking solace in the forces of the universe, the powers of love, the wisdom of old alchemical philosophies [...] and ancient myths, as he confronted both the precarious quality of the human condition and the dire political situation of the time" (Arcanum 8-9). Similarly, Mark Polizzotti has seen Breton's work during this era as emphasizing "the need for a spiritual component in the rebuilding of postwar society" (546). Breton's Osiris is not only the harbinger of a myth that surrealism has yet to bare, but also a signal of the regeneration of surrealism's dormant magical tendencies and of the marriage of that magic with the reformation of the physical world. It is with Arcanum 17, the French publication of which coincided with the esoterically themed surrealist exhibition of 1947, that surrealism's latent esoteric principles resonate with renewed optimistic immediacy. Breton writes: "Esotericism, with all due reservations about its basic principle, at least has the immense advantage of maintaining in a dynamic state the system of comparison, boundless in scope, available to man, which allows him to make connections linking objects that appear farthest apart and partially unveils to him the mechanism of universal symbolism" (87). While esoteric philosophy is often relegated to the fringes of abstract theoretical discourse, scholar Antoine Faivre has identified four fundamental elements to the esoteric form of thought: (1) symbolic and real correspondences, (2) theory of living nature, (3) presence of imagination and mediation, and (4) experience of transmutation (1013). Each of these elements, to varying degrees, can be located within the theories of Breton from his first manifesto to the post-war period. But it is not until Arcanum 17 and the Surrealist exhibitions that follow in the 1940s that esotericism becomes more than a latent strain of surrealism's mythic imaginary. Esotericism, while issuing forth in less visible guises through earlier writings of Breton, is brought forward emphatically here, and in surrealist work of the 1940s assumes a utopian role as the transformational antidote to war and loss.

It is also during this time period that Austrian architect and artist Frederick Kiesler becomes involved in surrealist exhibition design, formulating displays for the Art of This Century gallery in 1942, the Blood Flames exhibition at the Hugo Gallery in 1947, and in coordination with Breton, the Exposition Internationale du Surréalisme of 1947 at Galerie Maeght in Paris. Notably, Kiesler's theory of correalism, his manifesto for magic architecture, and his long pursuit of endlessness as embodied by his Endless House project are all directly charged by esotericism. Kiesler's work, which ranged from paintings to set and theater designs to exhibition displays to proposals for houses, was always invested with an intense spatial and plastic dimension. As one of the few architects to have worked directly with surrealist artists, and the one most responsible for the spatial organization of surrealist exhibitions in the 40s, Kiesler is surely the pre-eminent architect-artist of the surrealist movement. Even so, surrealism's translation into architecture has 
long been a subject of contention, and was never deeply probed by major figures like Breton. Breton's most extended discussion of the relationship between surrealism and architecture occurs in "Surrealist Situation of the Object" (1935). Quoting Dalí, Breton points to the "solidified desires" of art nouveau buildings, as well as to The Ideal Palace of the mailman Cheval. In addition, with reference to Antonio Gaudi's Sagrada Familia, he notes that "the form of art that blossomed in the magnificent church, all in vegetables and crustaceans, in Barcelona is now preparing its revenge" as surrealist tendencies are slowly finding their way into the works of such modernist architects as Le Corbusier (Manifestoes 261). Responding to this passage, Thomas Mical, in his recent edited volume Surrealism and Architecture, observes that "Breton was incapable of understanding the design/making/meaning of architecture as Dalí could, and explained the 'concrete irrationality' of modern architecture in the superficial exception of a wavy wall of Le Corbusier's Swiss Pavilion of the Cite Universitaire in Paris." Searching for a deeper relationship between surrealism and architecture, Mical asks the provocative question, "Can the Bretonian categorization of surrealist objects apply to spaces?" According to Mical, direct relationships between the two are rare, owing to a procedural distinction between works of sculpture and architecture. However, he identifies a possible connection via Breton's elaboration of Dalí's paranoid critical method which describes "the ability of the surrealist object to fuse two distinct images to produce 'uninterrupted successions of latencies' from the 'hidden real' of their origins" (5). These remarks are similar to observations by Haim Finkelstein, who has also seen a close analogy between surrealist conceptions of architecture and surrealist objects (111). Following on this, I wish to propose that Breton's surreal objects find rarified form in the architecture of Frederick Kiesler and that it was Kiesler's sustained development of esoteric thought forms that enabled this translation. The projects of Kiesler, dynamic as they are in visual and material terms, perform another kind of transformation, converting the terms of Breton's automatism, as well as Breton's conception of object making, into spatial propositions. The distillation of surrealist precepts into space was, in my view, catalyzed by the surrealists' renewed focus on esotericism in the 1940s and by the spatially suggestive nature of esoteric thought. A key figure within this context is Egyptologist R.A. Schwaller de Lubicz, whose esoteric philosophy and research on the temple of Luxor forms a veritable bridge between Breton's automatic processes and the architecture of Kiesler's endlessness.

Close examination of the writings of Schwaller de Lubicz (1887-1961) and Breton (1896-1966) reveals a provocative set of correspondences. Breton cites Schwaller de Lubicz while discussing eroticism in his "Introduction to the International Surrealist Exhibition 1959." Recognizing a flash of surrealist insight in "disciplines very different from our own," Breton points 
to Schwaller de Lubicz's assertion that, "While the sense of shame and aesthetics must be denied in eroticism, the sense of life and of the sacred cannot be denied without, at the same time, provoking the very negation of the erotic" (Surrealism and Painting 380). Franklin Rosemont mentions Schwaller de Lubicz in André Breton and the First Principles of Surrealism, citing him among the works of "esoteric or 'occult' philosophy" from which surrealists drew inspiration (3). In addition, translators Deborah and Robert Lawlor have pointed to Schwaller de Lubicz's close association with Hans Arp (The Temple in Man 8). Although these moments of recognition are revealing, whatever level of awareness each thinker may have had of the other is beyond the scope of this essay. I am less concerned with the question of influences than with parallel processes. In particular, I am interested in how the esoteric strain of surrealism resonates with Schwaller de Lubicz's research on the temple at Luxor and in the pathway that this opens for surrealism into the realm of architecture. Of special consideration here is the extent to which, for Breton, Kiesler, and Schwaller de Lubicz, changes in form and space are expressive of changes in consciousness. In this essay, I perform two comparisons between surrealism and architecture through a lens of esotericism. The first examines Schwaller de Lubicz's conclusions on the Luxor temple and their relation to Breton, and the second focuses upon Kiesler's translations of Luxor and Breton into space. I will conclude by speculating about the possibilities of esotericism for informing a crossdisciplinary view of architecture, space and time. While the writings of Breton and Kiesler have been widely analyzed, those of Schwaller de Lubicz have still received relatively little attention, perhaps owing to his having been labeled by critics as a mystic or occultist and to the suspicion with which he is still regarded among archeologists and historians. However, the network of reverberations between his temple research, the theories of Breton, and the architecture of Kiesler should strengthen Schwaller de Lubicz's position as a critical creative thinker of his time.

\section{Luxor, Schwaller de Lubicz and Breton}

R. A. Schwaller de Lubicz is known primarily for his contributions to Egyptology, owing to his exhaustive fifteen-year study of the Temple of Luxor. However, his life's research might be more precisely described as a philosophic investigation of consciousness. His early studies of chemistry, physics, and especially alchemy provided a physical grounding for his later investigations of the inner mind. According to Deborah and Robert Lawlor, "His unique and intuitive way of seeing, in combination with a technical and scientific education, gave him extraordinary insight into the values and objectives motivating ancient science and theology" (The Temple in Man 9). Emerging out of a long tradition of hermeticism and gnosticism, Schwaller de 
Lubicz sought to recover the lost knowledge of the ancients and, in so doing, to guide the initiate on his/her own quest for self knowledge. Ancient Egypt was the model for Schwaller de Lubicz's philosophy, a culture within whose monuments he saw a sacred science inscribed. His later life was devoted to reflecting on the meaning of Egyptian architecture and formulating a philosophy of becoming that drew the latent meaning out of Egypt's inert stones. The Temple of Luxor was, for Schwaller de Lubicz, the physical embodiment of human consciousness reflected in the symbolizing faculty of intelligence.

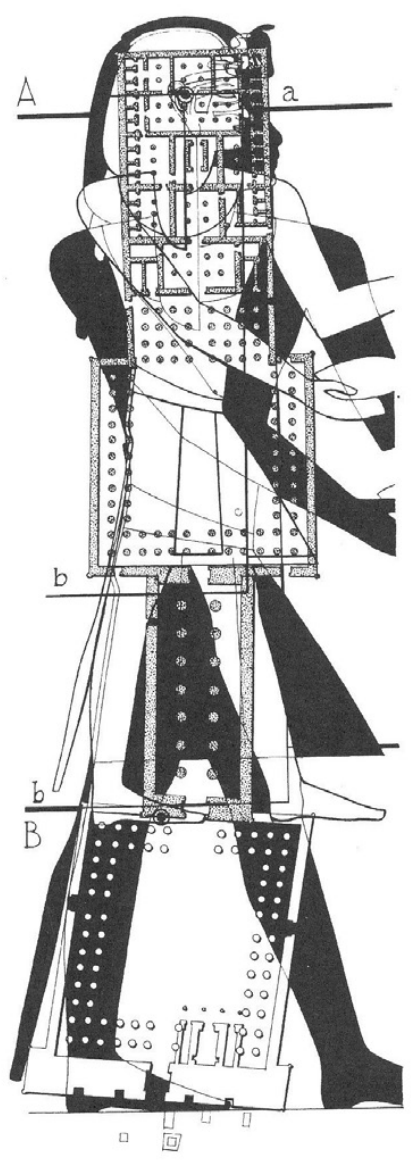

Figure 1: Superimposition of the royal principle depicted in room XII onto the Temple of Luxor at the two stages of its construction (third stage of Amenhotep III and Ramesses II) and at the two corresponding ages of his growth. R.A. Schwaller de Lubicz. Illustration by Lucie Lamy, 1940-1948. (Temple of Man 661). 
According to Schwaller de Lubicz, the architecture of the temple, through its precisely orchestrated geometries, numerologies, and symbols, exemplified the innate knowledge of the ancient Egyptians. His inquiries into Egyptian symbolization led him to speculate that in order to understand the meaning of Egyptian monuments, one would first need to discover, and then enter into, the ancient way of thinking. Schwaller de Lubicz's process of obsessively measuring, transcribing, and decoding every stone at the Temple of Luxor resulted in his thesis that the temple explained vital functions symbolically. Not surprisingly, given the subject matter of his research and views, the writings of Schwaller de Lubicz are dynamic and multi-layered fields. The concepts that he promotes, and the means by which they are elaborated, are constantly shifting, one term splitting, its components diverging, and the fragments later remerging as new unities. Appropriately, Robert Lawlor describes his writings as a "synapse" between two polarities of intelligence, the analytical and the analogical (Symbol 7). His ideas slide, oscillate, transform and exchange positions, in a kind of active process that parallels his understanding of the psyche. To the mind seeking to rationally comprehend Schwaller de Lubicz's texts, they can appear cryptic and contradictory. According to Deborah Lawlor, he writes "not with precise, logical definitions, but rather by talking around his subject, viewing it from subtly different perspectives so that the reader emerges with a deeper understanding than a sterile definition could give" (Nature 61). The multivalent lens that Schwaller de Lubicz applies to his understanding of consciousness is focused by primary principles that act as locaters within a substratum of shifting interior identities. In the sections that follow, I examine core aspects of his philosophy, focusing upon his theory of consciousness, spatial projection in the Luxor temple, and upon connections of these elements to surrealist thought.

\section{Functional Consciousness as Inner Knowing}

Before considering in depth the theories of Schwaller de Lubicz, it must be reiterated that his philosophy of consciousness and his understanding of the stone works of ancient Egypt are inherently conjoined. So thoroughly interdependent are his ideas concerning the nature of mind and his readings of Egyptian architecture that it becomes impossible to separate the two. Although his research on the science and philosophy of the ancient world began well in advance of his time spent in Egypt, his conclusions about the Temple of Luxor are confirmations and elaborations of his earlier works. He believed that in order to truly understand the work of the ancient builders, one would need to enter into their mentality, an operation that demanded a qualitative change on the part of student and scholar alike. The rational, scientific method was not equipped to deal with the vitalist 
mentality embodied by temple culture. Egypt was, for Schwaller de Lubicz, the source of a different kind of science, one that had been lost, and of "a type of education that - using the vital organs in which the nervous flux is transformed as well as the center (or 'nodes') of this flux - can awaken 'consciousness' of states that precede and transcend material forms" (The Temple in Man 17). The demands imposed upon the uninitiated, in order to enter into this way of thinking, required that Schwaller de Lubicz construct a system of correspondences. Thus, the accessibility of the ancient mentality was largely dependent upon Schwaller de Lubicz's capacity to communicate what he understood to be ancient principles. In his text Symbol and the Symbolic, "Schwaller de Lubicz examines symbolization or, rather, the symbolic method in general, not from the point of view of our contemporary use of symbols as conventional designations, abbreviations or as literary, metaphoric devices, but as the means for transmitting a precise suprarational knowledge and intuitive vision which, he contends, was a major aspect of ancient science" (9). Symbolization for Schwaller de Lubicz is a mechanism for elaborating a two-fold view of consciousness. Peter Tompkins summarizes this view in The Magic of Obelisks, noting that, according to Schwaller de Lubicz,

the ancient Egyptians distinguished two types of consciousness: an intelligence which knows this universe without having to reason it, and a cerebral intelligence, which Schwaller de Lubicz qualifies as that of 'fallen' Adamic man. Cerebral consciousness, peculiar to the animal kingdom and human anima, requires the faculty of registering notions that are only acts of comparison, and this faculty the Egyptians located in the cerebral cortex and the double cerebral lobes. (452)

The concept of innate knowledge, or functional consciousness, is a way of thinking that directly contrasts with cerebral consciousness. While cerebral consciousness "requires the object or the objectification of the concept, hence the placing of the concept in Time and Space," functional consciousness "conceives intuitively, but without yet formulating the concept." (Symbol 41). For Schwaller de Lubicz, this mode of thinking is continuous in time and resists objectification. Function is a process, an action, and an activity. Accordingly, he asserts:

Now, the notion of activity is essentially linked to a representation of a movement of the cause towards the effect; whether the movement be quantitative or qualitative ought not to concern us for the moment. One fact is certain: all movement requires a displacement from the cause to the effect. Displacement! It is impossible to disentangle the notion of movement from this notion of displacement, hence from space, and space defined by movement designates the notion of time. Time, Movement, Space, here are the elements of function, that is, of the development of the cause to the effect. (Nature 55-56) 
This philosophy is vitalistic, seeking truth in the living. The correlation of cause and effect, activity and resistance, are for Schwaller de Lubicz, primary elements of a worldview that is structured around absolute continuity. He writes, "Since, in the beginning of everything, the functions of which we speak are neither situated, limited, nor conditioned, but are with the absolute functions, I come to the following: Activity and that which undergoes it, which we know as resistance, are identical or of the same nature" (56). The data provided by the Temple of Luxor becomes material for fortifying many of Schwaller de Lubicz's primary concepts of continuity, including the law of crossing, the present moment, and the simultaneity of opposites. According to Schwaller de Lubicz, the law of crossing is the alternation of the observable with the imperceptible. It is the phenomenal appearance of alternation. He states in The Temple of Man, "All the images and analogies that we can imagine have the sole aim of evoking the unformulated or unformulable consciousness of the real meaning of the crossing. The tangible evokes the intangible by negation: this strange affirmation of an unformulated certainty that is the negation" (478). The principle of the present moment is similarly framed. It is for Schwaller de Lubicz "the passage from One to Two." He observes that "at each instant movement can only be completed or about to start. It cannot be otherwise, for it cannot be past and future 'at the same time."' The present moment is "that which compels the nucleus to divide in two" (51). These phenomena of alternation dissolve the boundaries of time and space, investing all matter with an animate life-force. Schwaller de Lubicz's philosophy is confirmed, in his view, by the architecture of the Luxor temple, which is for him the locus of continuous becoming. There, his vitalism reverberates against the organizational structure of inert stones, establishing a spatial projection of the Egyptian body and mind.

\section{Space and the Body I: Consciousness Inscribed}

What is so fascinating about Schwaller de Lubicz is that his theories of ancient consciousness, and the door to the ancient mentality, are ultimately opened through entirely rational means. From 1937-1952, Schwaller de Lubicz, with his wife Isha and their team, undertook a comprehensive survey of the Temple of Luxor, measuring and transcribing every stone, glyph, and joint, including every bas-relief and inscription. The result of his team's observations, recordings, and decipherment was a small book, The Temple in Man (1949), which presents Schwaller de Lubicz's conclusions about the temple and its embodied symbolization as key to the mentality of the Master Builders. This text, in addition to a larger work, The Temple of Man (1957), establishes the thesis that "the Temple of Luxor is indisputably devoted to the Human Microcosm," and that "the entire temple becomes a book explaining the secret functions of the organs and nerve centers" (The Temple in Man 
24). Schwaller de Lubicz's findings are established by extensive geometrical proofs, among which are included his calculations that the dimensions of the temple's various parts are governed by the proportioning systems established by the growth of the human body.

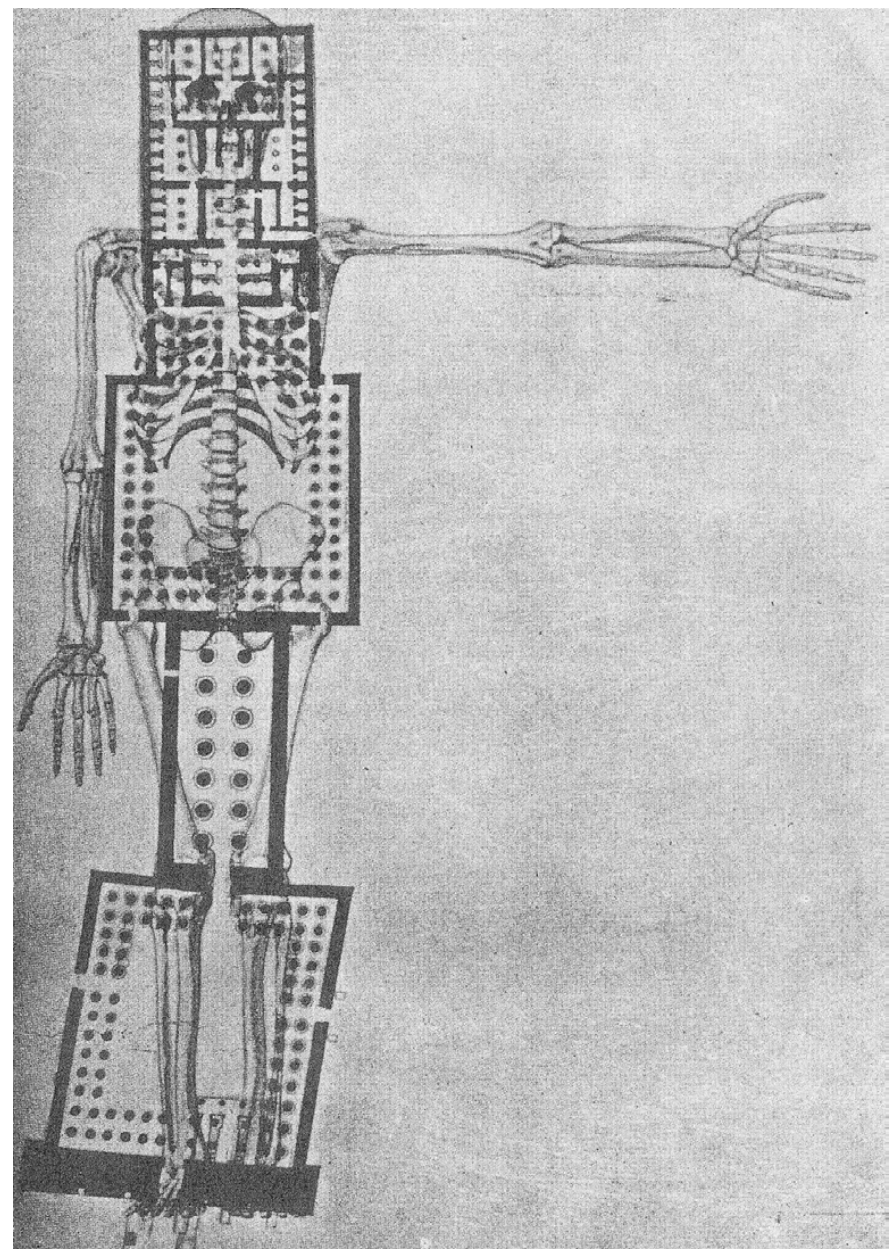

Figure 2: Projection of the plan of the Temple of Luxor on a human skeleton. R.A. Schwaller de Lubicz. Illustration by Lucie Lamy, 1940-1948. (Temple in Man 23).

The convergence of the human body with the temple is described as follows:

The outline of a human skeleton - traced according to anthropometrical methods and very carefully constructed, bone by bone - was superimposed on the general plan of the temple. The 
head (full face for the skeleton) is located exactly in the sanctuaries of the covered temple; the sanctuary of the barque of Amūn is in the oral cavity; the clavicles are marked by walls; the chest is located in the first hypostyle of the covered temple and ends with the temple's platform. The abdomen is represented by the peristyle court, and the pubis is locates exactly at the door separating this peristyle from the colonnade of Amūn. This marvelous colonnade is, in fact, dedicated to the femurs, the thighs; the knees are at the site of the gate in front of which sit the two colossi, marking the entrance to this colonnade. The tibias are in the court of Ramses, framed by the colossi, whose legs (tibias) are particularly pronounced. The little toe of our skeleton falls exactly at the northwest angle of the pylon. $(21-24)$

By relating the proportions and ratios of human growth to the primary dimensions of the Temple of Luxor, Schwaller de Lubicz links the architecture to the vital functions of the human body. These correspondences were initiated by Schwaller de Lubicz's discovery that the paving stones of the southern part of the temple revealed a human profile in mosaic.

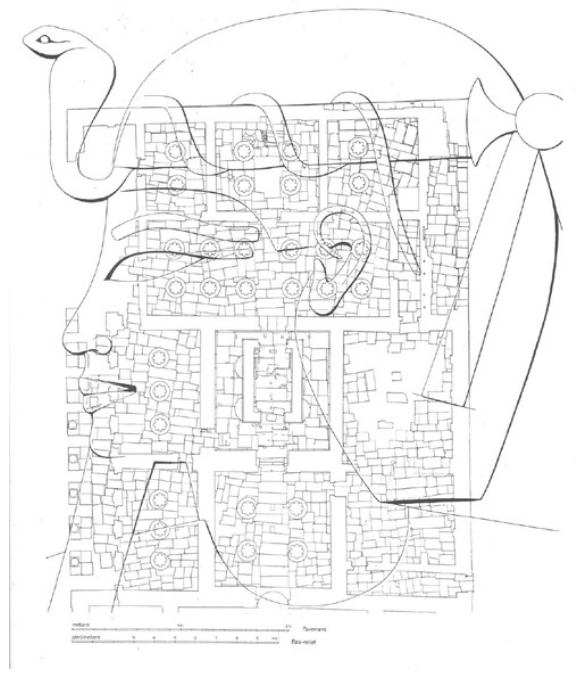

Figure 3: PLATE 36. The Profile of the King on the Mosaic. R.A. Schwaller de Lubicz. Illustration by Lucie Lamy, 1940-1948.

(Temple of Man 683).

Superimposition of the corresponding glands, organs, and nerve centers identifies the placement of key thresholds, stones, glyphs, and chapels. 


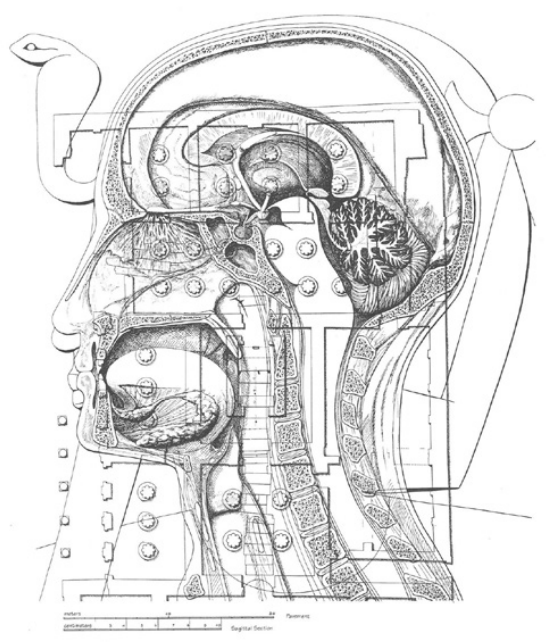

Figure 4: PLATE 38. The Controlling Centers of the Head in the Covered Temple. R.A. Schwaller de Lubicz. Illustration by Lucie Lamy, 1940-1948. (Temple of Man 687).

Schwaller de Lubicz notes of the head portion that the "crown of the skull, marked off in Egyptian figuration by a headband, a diadem, a headband or crown - is a veritable revelation with regard to psycho-spiritual knowledge of the Ancients. This is made clear by the placement of the principal organs of the Intellect and of all the control mechanisms of life in the various sanctuaries, whose figurations, texts, and architecture specify the purpose" (24). The sanctuary of the temple is the human head, where all the corresponding control centers are located, the origin of a "spiritual metabolism" in stone. Of the temple's embedded principles Schwaller de Lubicz writes:

Knowledge can only be synthetic; because of this it can only be intelligibly transcribed by the architectural monument, that is, by a simultaneity of plane and volume, accomplished in Egypt through the symbolique of the writing, the image, and the statuary. To this is added a complete architectural grammar, represented by the shape of the stone blocks: their joints, overlappings, and 'transparencies' and 'transpositions' in the walls comprise a subtle grammar in which the finish of a carving or it rough aspect, the absence of essential parts - such as the eye or the navel - the reversal of right and left, and so forth, play the role of accents, declensions, conjugations and conjunctions. (The Temple of Man 520)

While reading the architecture of the temple through subtle nuances 
of form, geometry, and proportion, Schwaller de Lubicz purports to make perceptible the symbolic dimensions of the ancient culture. This is accomplished through the device of measure, which is for Schwaller de Lubicz the definition of relationships. In the case of the Temple of Luxor these relationships include "the orientation axes that link the temple to cosmic influences, the stone joints that convey the numerical relationships appropriate to their locations in the temple, the dimensions of the figures, the offerings, the attributes, the placement of the hieroglyphs in relation to the images and their ritual meanings" in addition to the "'transparencies' and 'transpositions' connecting one side of a wall to what is conveyed on the opposite side in the adjoining room" (xxvii). All of these measures are part of a system through which Schwaller de Lubicz asserts the relationship between the temple and physiological as well as conscious processes. His conclusions are presented as evidence of pharaonic thinking, of "a rigorous method dictated by myth and symbolic philosophy" (59). By surveying every stone, glyph, and joint in the Temple of Luxor, and by correlating this information to the conscious faculties of the ancients, Schwaller de Lubicz wholly reframes relationships between mind, matter, and the body. His carefully recorded mathematical calculations - understood not as geometric abstractions, but as shifting relationships - become the testimony of a displaced consciousness, a means of verifying a mental faculty that has been lost, but that can be reentered through symbolizations.

\section{Schwaller de Lubicz, Breton and the Object}

Schwaller de Lubicz's conclusions regarding the systematizing structure of Egyptian symbolization align in several key ways with the theoretical tenets of André Breton. The intuitive aspect of Schwaller de Lubicz's inner knowing shares points of contact with psychic automatism. For both writers, functional consciousness and psychic automatism form the core of a philosophy of mind which is directly opposed to that of structured logic and which emphasizes modes of thought that are not based upon faculties of comparison. In addition, both domains are accessed by a deep descent, on the one hand into the ancient mind, and on the other into the depths of the unconscious. Franklin Rosemont has emphasized that Breton's automatism was not a surface-bound operation, but a "plunge below", that was closer to shamanism or other trance states (21). And Breton, in his "The Automatic Message" of 1933, refers to the psychologist, F. W. H. Myers, who wrote of "a form of internal hearing [how strange] [...]. It exists in powerful and complex clusters of conceptions that are formulated outside [some would say beyond] articulated language and reasoned thought" (What is Surrealism? 109). The primacy of auditory faculties is key for both Breton and Schwaller de Lubicz. Breton described automatism first and foremost as a verbo-auditive process, 
maintaining "I believe blindly ... blindly, with a blindness that covers all visible things - in the triumph auditorily of what is unverifiable visually" (108). Similarly, it has been noted by the Lawlors that "the pharaonic intelligence that Schwaller de Lubicz reveals to us was not the visualizing, analytical mentality we know but a sonar-intuitional mode" (The Temple in Man 11). Thus "one must learn to listen to the symbolic image, allowing it to enter into and pervade one's consciousness, as would a musical tone which directly resonates with the inner being, unimpeded by the surface mentality" (Symbol 11).

Another overlap between Breton and Schwaller de Lubicz is that, for each, access to an alternative form of consciousness is enabled by temporal continuity. For Breton, temporal continuity is a matter of registering succeeding impressions automatically, while in Schwaller de Lubicz we find temporal succession in his persistent linking of cause and effect. The deobjectification that Schwaller de Lubicz stresses through function as activity is manifest for Breton in a similar form of psychical continuity as he writes in the Manifesto of Surrealism (1924): “a monologue spoken as rapidly as possible without any intervention on the part of the critical faculties, a monologue consequently unencumbered by the slightest inhibition and which was, as closely as possible, akin to spoken thought" (Manifestoes 23). Although Schwaller de Lubicz insists that the functional order of consciousness has no chronology - since between successive stages, no time exists - he does divide the functioning of thought into the following four stages: (1) selection, which is the faculty of choice, (2) polarization, which separates and distinguishes, (3) harmonization, which connects, attracts and repels, and (4) individuation, through which is formed a new unity (Nature 82). It is important to recognize here that these interior stages of consciousness - Schwaller de Lubicz's activities - directly correspond to the physical activities through which the surrealist object was actually formulated in the exterior world. Selection, polarization, harmonization, and individuation are descriptive of the means by which raw materials - found objects - are reformed via the surrealist object proper. This is to say that Schwaller de Lubicz's functional consciousness is the internal equivalent of the material processes necessary in order to externalize psychic automatism through the production of artifacts. Schwaller de Lubicz's central concern, how to think without objectifying, actually makes visible the physical processes that might lead to the making of new objects and images. Here, we move closer to understanding the spatial potential of surrealist objects, pointed to by Mical through Dali's "uninterrupted successions of latencies" (5).

Schwaller de Lubicz's trajectory toward unification resounds with Mary Ann Caws' observation that surrealism, "in Breton's view, is primarily a unifying force. Against all separations and specializations it poses its single most important visual image, the communicating vessels already perceived 
in Le Surréalisme et la peinture of 1928" (72). Caws also points to Breton's definition of surrealism as a conductor (fil conducteur), and notes that in such a description, "Breton is faithful to the imagery of electricity. The same image is applied to the distant elements of an image, and to any bringing together, an action to which surrealism can be considered to have devoted itself in large part" (73). The bringing together of disparate elements in pursuit of a new time-space is a phenomenon that is visible when "The Surrealist places A with E, never concerning himself with what should precede or follow what; all elements are seen as simultaneous" (54). This view is consistent with that of Schwaller de Lubicz, who insists that even as the stages of functional consciousness can be identified, "there is no separation among them" and, thus, "polarization becomes analogous to division, selection analogous to affinity, harmonization analogous to fecundation and determination analogous to individuation" (Nature 82). In Schwaller de Lubicz's terms, therefore, the surrealist object can be re-framed not as an object per se, but as an internal function - a vital activity. Schwaller de Lubicz writes, "In our symbolic approach it is understood that the individual is itself composed of a group, but through this group it has become an individuality, that is, a unity independent from other similar unities. Thus, each part of what composes it can no longer be regarded as an individuality and can no longer even be objectified. Thus, one may only speak of qualitative or energetic 'Principles'”'(Symbol 57-58). As Deborah Lawlor points out, for Schwaller de Lubicz "any object is the 'signature' of the 'abstract' functions which entered into its formation" (Nature 60). Lawlor elaborates the relationship between function and phases as follows:

The function forms the link between the Real and the particular. Because the functions exist in us, because in fact man represents a synthesis of all functions, he can recognize and know through functional identity both the particular instance of a functional activity and its general, ever-present potentiality understood abstractly. This form of knowing leads to a perception of things as vital processes rather than as dead, disconnected facts: 'Nothing is separated outside our senses; as a nebula gestates a Universe, so a woman's womb gestates a human world. Function and phases are the same: who looks at one sees the other.' (64)

Schwaller de Lubicz's reciprocal relationships between interior and exterior, object and field, also find parallels in Breton. However, for Breton, it is not so much a matter of resisting objectification, but rather of facilitating the object's shift across mental and physical boundaries. Breton's thoughts on the role of objects, first as evidence of an autonomous mental process, and later, as a mediating device between mind and matter, are quite different from the animism of Schwaller de Lubicz's mental processes. Noting that the "object in surrealism was understood to mediate between the competing 
realities of the mind and the external world, dialectically reconciling the two," Janine Mileaf points to Breton's early aspiration, expressed in "Introduction to the Discourse on the Paucity of Reality" (1924): "It is to fulfill this desire for perpetual verification that I recently came up with a proposals to fabricate, in so far as possible, several of those objects that one only glimpses in dreams and that seem utterly unjustifiable both in terms of their usefulness and their entertainment value" (95). This early idea of the object as a 'testimony' or 'proof' of the unconscious realm is contrasted with Breton's later quest to assert "the interaction of the external world and the imagination" (95). Even though Breton's views about surrealist objects change between 1924 and 1934, his ideas never approach the animate character of Schwaller de Lubicz. Insisting that objects can never be seen as fixed or static entities, Schwaller de Lubicz uses the example of wood to demonstrate the activity it necessarily engenders. He writes:

[...] observe that the wood of a plant densifies to a certain point which cannot be surpassed within the framework of its species. Thereafter, in the progress of the sapwood, the hardest wood becomes marrow, from which comes the mounting flux mixed with new sap; then, aired by the leaves, it descends again under the bark, on the one hand to be re-embodied, and on the other, to become the new seed. Its respirations then include, from the lowest to the highest, humidity, air, heat, light: the bearers of spiritual substance. Depending on the degree of subtilization of this circuit, flesh, seed, nervous flux and Spirit - mental and spiritual - are animated, from metal to man. (Nature 89)

As is made clear in the above excerpt, for Schwaller de Lubicz, wood is not an object, but a set of processes - a continuous succession of vital functions. These functions are variable in terms of scale as well as substance. Wood oscillates from solid to fluid, visible to invisible in an animated exchange with everything that surrounds it, everything that gives it form and definition.

\section{Luxor, Kiesler and Endlessness}

The writings of Frederick Kiesler (1890-1965), more than those of Breton or any other surrealist artist, map very directly onto core principles of esotericism as defined by Faivre. Kiesler's theory of correalism is, first and foremost, a system of correspondences - a network of analogies. In addition, his idea of biotechnique defines the relationship between living nature and design, linking the act of building to natural processes. In Kiesler's galaxies, paintings that he views as constellations of forces, we see the importance he attached to imagination and mediation through images and symbols. Most significantly, in Kiesler's embrace of "the law of creative transmutation" as 
both process and synthesis we understand the terms by which he transforms function from a utilitarian concept to an internal activity, a transformation that is paralleled in Schwaller de Lubicz (Pseudo-Functionalism 30). These four fundamental elements of Kiesler's thought demonstrate his propensity for converting esoteric standards into spatially driven processes. But Kiesler's conversions are more than just this. His work effectively develops the architectural possibilities of Schwaller de Lubicz's esotericism, filtering the Luxor temple through the theories of Breton. As a spatial conductor, his architecture shifts the terms of psychic automatism from an interior mental process to one centered upon the body in space. His body-centered universe takes up the projection at Luxor, converting Luxor's embodied representation into a space of direct performance. The correspondences among Kiesler, Schwaller de Lubicz, and Breton can be understood through three primary themes that will be analyzed here: absolute continuity, function vs. nonfunction, and the space of direct contact.

\section{Continuity as Animate Space}

For Kiesler, absolute continuity of time, space, body and material was fundamental to a new form of architecture that was calibrated to the needs of the human psyche. Kiesler's pursuit of endlessness, exemplified by his numerous elaborations of the Endless House, became a thread that wove much of his life's work together and fostered a dissolution of the formal barriers of architectural separation - walls, floors, and ceilings - as well as the disciplinary dissolution of painting, sculpture, and architecture. In his article "Correalism and Biotechnique" of 1939, Kiesler writes,

What we call 'forms', whether they are natural or artificial, are only the visible trading posts of integrating and disintegrating forces mutating at low rates of speed. Reality consists of these two categories of forces which inter-act constantly in visible and invisible configurations. This exchange of inter-acting forces I call COREALITY, and the science of its relationships CORREALISM. The term "correalism" expresses the dynamics of continual interaction between man and his natural and technological environments. (68)

Kiesler's theory of correalism, like Schwaller de Lubicz's functional consciousness, dissolved the boundaries of objects in order to yield an animate spatial field. In "Manifesto on Correalism," he states, "Through a change in the relative balance of vital forces, the pole of attraction and interest will shift from concrete facts (1) to objectives (2) or from objectives to the object (3) or a similar shift may continue the process" (94). The reverberations established by Kiesler's continuity are also related to Breton's thoughts on analogical thinking as put forward in Communicating Vessels. Therein, Breton states his 
aim, whether in reality or in dream, "to make the elements pass through the same network: condensation, displacement, substitutions, alterations" (109). Here we see that Breton's thinking on objects in 1932 becomes charged with a dynamic spatially suggestive quality, a phenomenon that was previously noted in Schwaller de Lubicz's readings of Luxor, and one that Kielser advances through his correalist spatial practice. In a footnote, Breton elaborates on this position:

To compare two objects as far distant as possible one from the other or, by any other method, to confront them in a brusque and striking manner, remains the highest task to which poetry can ever aspire. Its unequaled, unique power should tend more and more to practice drawing out the concrete unity of the two terms placed in relation and to communicate to each of them, whatever it may be, a vigor that it lacked as long as it was considered in isolation. What must be undone is the formal opposition of these two terms which resided in the imperfect, infantile idea we have of nature, of the exteriority of time and space. The stronger the element of immediate unlikeness appears, the more strongly it should be surmounted and denied. The whole meaning of the object is at stake. So two different bodies, rubbed one against the other, attain through that spark their supreme unity in fire; thus iron and water reach their common, admirable resolution in blood, and so on. Extreme particularity could not be what this way of seeing and of feeling would ever come to grief over; thus architectural decoration and butter are perfectly conjugated in the Tibetan torma, and so on. (109)

In the above passage, we see how Breton's interest in analogical thinking approaches the esoteric correspondences which define the work Kiesler and Schwaller de Lubicz. By the 1940s, this dimension of esoteric thought, latent in Breton's texts of the 30s, was ready to be initiated into space through Kiesler's architectural propositions.

\section{Function, Activity and Non-function}

Much like Schwaller de Lubicz, Kiesler describes function in terms of animate activity, rather than according to utilitarian concerns. In Correalism and Biotechnique, he provides a new definition of function for architecture, asserting that, "We cannot conceive of function as something static, else growth would cease. The inter-action of environment and man, and evolution of that inter-action to new possibilities, is not a direct result of environment. It is rather the development by environment of something which was already inherent physiologically in the organism" (75). For Kiesler, "The new designer will therefore define function as a specific nucleus to 
actions" (75). Kiesler's functionalism is a living process, a matter of inner - not outer - necessity. This functionalism mirrors the coordinated, multidimensional terms of Schwaller de Lubicz's consciousness. Kiesler writes, "Each element of a construction or a city, whether it is painting or sculpture, interior installation, or technical equipment, is conceived not as the exclusive expression of a single function, but as a nucleus of possibilities which will be developed through coordination with other elements" (Manifesto 95).

Kiesler's vigorous opposition to utilitarian functionalism is also inscribed by the views of Breton, who, through the making of surrealist objects, sought to usurp the world of utility and purpose. The necessity to subvert functional utility is emphasized by Breton in the "Surrealist Situation of the Object," wherein he states,

There would be cleverly constructed machines that would have no use; minutely detailed maps of immense cities would be drawn up, cities which, however many we are, we would feel forever incapable of founding, which would at least classify present and future capitals. Absurd, highly perfected automata, which would do nothing the way anyone else does, would be responsible for giving us a correct idea of action. (Manifestoes 277)

Along these lines, J. H. Matthews notes that, "Behind the surrealist's faith in imagination lies contempt for the stasis of the familiar and, at the same time, curiosity about an ever-changing world of possibilities. So the function of the surrealist object is to terminate a confinement imposed on things by their usefulness" (190). This protest against utilitarianism focuses for us the real function of the surrealist object. For Breton, function has a twofold usefulness. Surrealist objects are useful in so much as they circumvent or otherwise challenge an external opposition imposed by the utility of the mundane, everyday world. Thus, Breton's conception of function as an external object-obstacle, while contrasting with Schwaller de Lubicz's conception of function as an internal, active process, does find a parallel spatial role in Kiesler's protest. For all three figures, critical importance is attached to the role of function and to the status of the object with respect to the mind. Breton, especially in his writings on objects, focused upon re-framing the external world through the making of new objects and by subverting external function. By contrast, Kiesler and Schwaller de Lubicz sought to reframe consciousness by dissolving the object and by increasing internal function. In both Kiesler and Schwaller de Lubicz, the shift from outer to inner reality was commensurate with the object's disappearance, and with an increased spatial understanding. 


\section{Space and the Body II: From the Psyche to Direct Contact}

Kiesler's continuous architecture, much like Breton's early automatism, is conceived as an autonomous mental process, a way of building that aligns with innermost needs. His direct building, a process of designing through direct contact, advances an architecture that is psychical even before it is physical. In "Magic Architecture" he writes "Magic Architecture is a generator. It can operate on any scale. Any cell of habitation is a nucleus for a power house of joyful living" (18). In freeing the act of building from wealth, material limitations, and social power, he asserts the absolute primacy of mental processes in design, and combines the immediacy of space with the immediacy of living nature. For Kiesler, in his "Manifesto on Correalism," "The House is a living organism, not just an arrangement of dead material: it lives as a whole in its details. The house is the skin of the human body" (92). Kiesler takes this analogy further in "Pseudo-Functionalism in Modern Architecture," comparing the genesis of a human being to the making of spatial enclosure. For him, space proceeds from a nuclear conception "out of a single germ cell which contained the whole and which slowly developed into the separate floors and the rooms of man. This cell, owing its origin to the erotic and creative instinct and not to any intellectual mandate, is the nucleus of the human edifice" (29). Drawing upon natural will, instinct, and natural forces, Kiesler affirms the innermost nature of architectural production.

Kiesler's ideas necessitate a new way of projecting space, one that is not dependent on the architectural plan or footprint. According to him, "If we had progressed to the point of working freely, that is, of creating a concrete thing free from the realities of routine, then we architects would surely not plan buildings by drawing floor plans; we would first of all (and I have been trying to do this for many years) project on paper the nucleus of the dwelling universe: the nervous system of the house" (29). Kiesler's insistence that the nervous system is the dwelling universe corresponds precisely with Schwaller de Lubicz's conclusions on the Luxor temple. However, in Kiesler, such a relationship is not dependent upon the architectural representation, but rather is a function of the body's direct activity in space. Kiesler transforms the plan of the nervous system into the space of direct encounter. Many of his models for the Endless House were realized at the scale of his body. Photographs of him working on the models frequently show him inside, the walls wrapping around him. Lisa Phillips notes that "he was observed to sketch out plans in space with his body following the lines of the imagined structure" (128). Kiesler sees no difference between the dwelling and its conception asserting that, "The architect is his house. The house is the architect" (Manifesto 93). While maintaining the esoteric qualities of Schwaller de Lubicz's thought, Kiesler converts the architecture of the psyche - as revealed by the Luxor plan - into a performative process. For him, 
the act of building is still a mental projection, but one that simultaneously envelops the body with tactile immediacy.

\title{
Esoteric Space and Symbolization
}

\author{
"A power cannot act against itself; it needs an \\ opposition. Thus the form of a volume results from \\ a struggle between movement, the disaggregating \\ revolt of matter, and the contracting power on Spirit; \\ the appearance of this double effect is life, which we \\ translate by the specific numbers of form-volumes, \\ because it is this life that manifests through volumes."
}

R.A. Schwaller de Lubicz (The Temple of Man 106)

\begin{abstract}
"A house is a volume in which people live polydimensionally. It is the sum of every possible movement its inhabitants can make within it; and these movements in turn are imbued with the flux of instinct."
\end{abstract}

Frederick Kiesler (Pseudo-Functionalism 32)

The examples of architecture that Breton cites in order to demonstrate surrealism's influence - the palace of Cheval, the church of Gaudi, and the art nouveau facades - are those which have visual antecedents in the imagery of surrealist painting. They demonstrate how surrealism's two-dimensional representations found physical, material form through translations that seem to have been more literal than conceptual. The work of Kiesler, however, demonstrates a more nuanced understanding of primary surrealist concepts, one that adapts them to the animate nature of esoteric philosophy. In so doing, Kiesler dissolves the symbolization inherent in the surrealist object, as well as that embodied by the Luxor plan. The spatial and temporal qualities of esoteric thought seem to have contributed significantly to Kiesler's vision, facilitating a transformation into architecture of surrealist themes. The language of esotericism is complex, multi-layered, and poly-dimensional. It is built of correspondences, resonances, forces, and transmissions. It is characterized by active fields and by subtle exchanges between interior and exterior. It is hierarchically structured. Its light is illuminating. In addition, it is charged by the imagination and by the experience of transmutation, metamorphosis, or the passage from one plane to another. It is, in sum, an intensely spatial composite of phenomena - a wholly synthetic language that constructs depth, mediates perception, and inspires movement. The persistent linking of parts energizes the territory of esotericism with palpable tactility and constructive possibility. In addition to serving Kiesler's work on 
the Endless House, this language proved particularly adept at reconciling differences among objects and ideas through exhibition design, bringing the work of many artists together within a coordinated field of exchanges. It is natural then that Kiesler should also forge a unity among the disciplines of painting, sculpture and architecture, dissolving the boundaries of plastic media.

In Symbol and the Symbolic, Schwaller de Lubicz states, "Whether it is a natural or combined image, or a conventional sign, the property of a symbol is to be a synthesis" (49). This synthetic, non-objective view of symbolization is consistent with Kiesler's vision, but it is a view that contrasts sharply with the image-object universe of Breton. Kiesler converts the Bretonian symbol into a set of resonances and dynamic possibilities. For both Schwaller de Lubicz and Kiesler, the symbol as conventional sign is completely transcended and becomes fully functioning within their conception of the exterior environment. This allows Schwaller de Lubicz to interpret the Temple of Luxor as a cosmic reality and a projection of the seed of consciousness. It allows Kiesler to shift the terms of architectural production to the human psyche and to relocate the matrix of the body - the synthesis of psychical projection - within the immediate sphere of the architect. According to Schwaller de Lubicz, "it is obvious for example, that the 'matrix image' is merely a method and not a final attainment and that it should be possible 'to objectify,' in a higher form of intelligence, a continuum of four-dimensional volume just as we now do with Euclidean volume" (40). This statement echoes Breton's distinguishing feature of surrealism, "the desire to objectify," but shifts Breton's object into an ever-changing, temporal domain (Surrealism and Painting 277). Schwaller de Lubicz, while working through obsessively rational processes of measuring and deciphering, provides access to a space, a mentality and a universe that is supra-rational, but yet is intricately bound to the projection of this ever-changing image. Kiesler, channeling the image through the body in action, leaves the walls, the floors, and the ceiling unhinged.

\section{Works Cited}

Breton, André. Arcanum 17. Trans. Zack Rogow. Los Angeles: Sun and Moon, 1994. Print.

- Communicating Vessels. Trans. Mary Ann Caws and Geoffrey T. Harris. Lincoln: U of Nebraska P, 1990. Print.

- Surrealism and Painting. Trans. Simon Watson Taylor. Boston: MFA Publications, 2002. Print.

- "Surrealist Situation of the Object." Manifestoes of Surrealism. Trans. Richard Seaver and Helen R. Lane. Ann Arbor: U of Michigan P, 1972. 25578. Print. 
-. "The Automatic Message." What is Surrealism? Selected Writings. Ed. Franklin Rosemont. London: Pluto P, 1978. 97-119. Print.

Bogner, Dieter, ed. Frederick Kiesler: Endless House 1947-1961. Ostfildern-Ruit: Hatje Cantz, 2003. Print.

Caws, Mary Ann. André Breton. New York: Twayne, 1971. Print.

Faivre, Antoine. Access to Western Esotericism. Albany: State U of New York P, 1994. Print.

Finkelstein, Haim. Surrealism and the Crisis of the Object. Ann Arbor: UMI Research P, 1979. Print.

Kiesler, Frederick. "Correalism and Biotechnique." Rethinking Technology. Ed. William Braham and Jonathan A. Hale. London: Routledge, 2006. 66-79. Print.

_. "Magic Architecture." Friedrich Kiesler: Endless House. Ed. Dieter Bogner. Ostfildern-Ruit: Hatje Cantz, 2003. 16-21. Print.

_. "Manifesto on Correalism." Frederick J. Kiesler: Endless Space. Eds. Dieter Bogner and Peter Noever. Ostfildern-Ruit: Hatje Cantz, 2001. 92-99. Print.

- "Pseudo-Functionalism in Modern Architecture." Friedrich Kiesler:

Endless House. Ed. Dieter Bogner. Ostfildern-Ruit: Hatje Cantz Verlag, 2003. 29-34. Print.

Mathews, J. H. Languages of Surrealism. Columbia: U of Missouri P, 1986. Print. Mical, Thomas, ed. Surrealism and Architecture. London: Routledge, 2005. Print.

Mileaf, Janine. Please Touch. Lebanon, N.H.: University Press of New England, 2010. Print.

Philips, Lisa. Frederick Kiesler. New York: Whitney Museum of American Art, 1989. Print.

Polizzotti, Mark. Revolution of the Mind: The Life of André Breton. New York: Farrar, Straus and Giroux, 1995. Print.

Rosemont, Franklin. André Breton and the First Principles of Surrealism. London: Pluto P, 1978. Print.

Schwaller de Lubicz, R.A. Nature Word. Trans. Deborah Lawlor. Rochester, VT: Inner Traditions, 1990. Print.

- Symbol and the Symbolic. Trans. Robert and Deborah Lawlor. Rochester, VT: Inner Traditions, 1981. Print.

- The Temple in Man. Trans. Robert and Deborah Lawlor. Rochester, VT: Inner Traditions, 1981. Print.

- The Temple of Man. Trans. Robert and Deborah Lawlor. Rochester, VT: Inner Traditions, 1998. Print.

Tompkins, Peter. The Magic of Obelisks. New York: Harper and Row, 1981. Print. 